\title{
PENINGKATAN HASIL BELAJAR IPA MATERI PROSES PERSILANGAN DENGAN METODE TUTOR SEBAYA DI SMP NEGERI 3 TRENGGALEK
}

\author{
Tutik Wahyuningsih ${ }^{1)}$ \\ 1) SMP Negeri 3 Trenggalek \\ tutikwahyuningsih727@yahoo.com
}

\begin{abstract}
ABSTRAK: Tujuan penelitian ini untuk mendapatkan gambaran objektif tentang peningkatan hasil belajar IPA materi proses persilangan melalui metode Tutor Sebaya pada siswa kelas IXD semester 2 Tahun Pelajaran 2017/2018 SMP Negeri 3 Trenggalek. Dengan rumusan masalah, bagaimanakah peningkatan hasil belajar IPA materi proses persilangan dengan metode Tutor Sebaya pada siswa kelas IXD semester 2 Tahun Pelajaran 2017/2018 SMP Negeri 3 Trenggalek. Subjek yang diteliti adalah siswa kelas IXD SMP Negeri 3 Trenggalek pada semester 2 Tahun Pelajaran 2017/2018. Objek Penelitian Tindakan Kelas ini menggunakan metode pembelajaran Tutor Sebaya. Metode yang digunakan dalam penelitian yaitu menggunakan Metode Penclitian Tindakkan (PTK). Berdasarkan hasil penelitian dalam setiap siklus mengalami peningkatan. Siklus I Jumlah siswa yang tuntas $62,5 \%$ sedangkan siklus $181,25 \%$. Nilai rata - rata kelas siklus 1 69,37 \% sedangkan siklus II 77,50\%, sehingga dari penelitian tindakan kelas ini dapat diambil kesimpulan bahwa penggunaan metode pembelajaran tutor sebaya dapat meningkatkan hasil belajar siswa kelas IX D di SMP Negeri 3 Trenggalek
\end{abstract}

Kata kunci : Tutor Sebaya, Hasil Belajar, Persilangan

ABSTRACT: The purpose of this study was to obtain an objective picture of the improvement of science learning outcomes in the process of crossing through the peer tutor method for semester 2 IXD students in the 2017/2018 academic year in SMP Negeri 3 Trenggalek. With the formulation of the problem, how is the increase in science learning outcomes material crossing process with Peer Tutor method in semester 2 IXD students of 2017/2018 Academic Year SMP Negeri 3 Trenggalek. The subjects studied were students of class IXD of SMP Negeri 3 Trenggalek in semester 2 of 2017/2018 Academic Year. This Classroom Action Research object uses the Peer Tutor learning method. The method used in the research is using the Action Research Method (CAR). Based on the results of research in each cycle has increased. Cycle I The number of students who completed $62.5 \%$ while the first cycle was $81.25 \%$. The average grade of cycle 1 is $69.37 \%$ while the second cycle is $77.50 \%$, so that from this class action research it can be concluded that the use of peer tutoring learning methods can improve the learning outcomes of class IX D students in SMP Negeri 3 Trenggalek

Keywords: Peer Tutors, Learning Outcomes, Crosses

\section{PENDAHULUAN}

Pembelajaran IPA adalah pembelajaran yang mempelajari tentang kumpulan teori, penerapan yang berdasarkan teori dan eksperimen melalui metode ilmiah seperti observasi dan eksperimen. Serta menurut sikap ilmiah seperti rasa ingin tahu, terbuka, 
jujur, dan sebagai pelajaran IPA di SMP pada masa sekarang menggunakan sistem keterpaduan, yaitu memadukan antara 3 disiplin ilmu fisika, kimia, dan biologi. Mata pelajaran IPA berkaitan langsung dengan diri sendiri dan alam sekitar secara ilmiah. Pendekatan yang diterapkan dalam menyajikan harus memadukan antara proses pengalaman, proses sains dan pemahaman produk teknologi dalam bentuk pengalaman yang berdampak pada sikap siswa dalam mempelajari IPA.

Berdasarkan hasil pengamatan dan observasi awal yang telah dilakukan pada siswa kelas IX SMP Negeri 3 Trenggalek pencapaian nilai standar maksimum tidak mudah dicapai oleh siswa terutama dalam pelajaran IPA. Hal ini disebabkan oleh beberapa faktor antara lain siswa cenderung pasif, kurang kreatif dan enggan untuk bertanya walaupun ada yang mereka tidak mengerti. Selain itu, pembelajaran cenderung didominasi oleh guru. Kondisi ini bertentangan dengan tuntutan KTSP menerapakan pembelajaran yang berpusat pada siswa.

Rendahnya prestasi siswa dapat dilihat dari perolehan nilai ulangan harian siswa kelas IXD SMP Negeri 3 Trenggalek. Kondisi yang seperti ini tentunya sangat tidak diharapkan dalam proses belajar mengajar, walaupun guru telah berusaha menciptakan pembelajaran agar siswa lebih aktif. Kondisi tersebut jika tidak dicarikan alternatif pemecahan masalahnya, maka guru tetap sebagai sumber informasi satu-satunya di kelas (teacher centered), tidak ada tukar informasi, penguasaan konsep dan hasil belajar IPA siswa tetap rendah, dan pembelajaran IPA jadi membosankan. Salah satu metode pembelajaran yang diharapkan dapat meningkatkan prestasi belajar siswa adalah metode pembelajaran tutor sebaya. Menurut Conny R. Semiawan (1990), metode tutor sebaya adalah upaya untuk mengoptimalkan kemampuan siswa yang berprestasi dalam satu kelas untuk mengajarkan atau menularkan kepada teman sebaya mereka yang kurang berprestasi sehingga siswa yang kurang berprestasi tidak mengalamai ketinggalan.

Lebih lanjut Herianto (2010), menyatakan bahwa tutor sebaya merupakan sekelompok siswa yang telah tuntas terhadap bahan pelajaran, dan memberikan bantuan kepada siswa yang mengalami kesulitan dalam memahami bahan pelajaran yang dipelajarinya. Seorang atau beberapa orang siswa yang ditunjuk oleh guru, untuk membantu guru dalam melakukan bimbingan terhadap kawan sekelas.

Berdasarkan latar belakang yang telah diuraikan di atas, perlu dilakukan penelitian tindakan kelas dengan judul "Peningkatan Hasil Belajar IPA Materi Proses Persilangan Dengan Metode Tutor Sebaya Pada Siswa Kelas IXD Semester 2 Tahun Pelajaran 2017/2018 SMP Negeri 3 Trenggalek”. Melalui Penelitian ini diharapkan dapat meningkatkan aktivitas belajar siswa dan prestasi belajar siswa kelas IXD SMP Negeri 3 Trenggalek. 


\section{KAJIAN PUSTAKA}

Leo Sutrisno (2008:25) mengemukakan "hasil belajar merupakan gambaran tingkat penguasaan siswa terhadap sasaran belajar pada topik bahasan yang dieksperimankan, yang diukur dengan berdasarkan jumlah skor jawaban benar pada soal yang disusun sesuai dengan sasaran belajar”. Menurut Usman, (2002) “ Belajar dapat diartikan sebagai proses perubahan tingkah laku pada diri individu berkat adanya interaksi antara individu dan individu dengan lingkungannya”. Dalam pengertian ini ada kata perubahan yang berarti bahwa seseorang telah mengalami proses belajar, ia akan mengalami perubahan tingkah laku, baik aspek pengetahuan, keterampilannya, maupun aspek sikapnya.

Menurut Hamalik (2008) Tingkah laku manusia terdiri dari sejumlah aspek. Hasil belajar akan tampak pada setiap perubahan pada setiap aspek-aspek tersebut. Adapun aspek-aspek itu adalah pengetahuan, pengertian, kebiasaan, keterampilan, apresiasi, emosional, hubungan sosial, jasmani, etis atau budi pekerti dan sikap.

Dari pendapat di atas dapat disimpulkan bahwa hasil belajar adalah kemampuan keterampilan, sikap dan keterampilan yang diperoleh siswa setelah ia menerima perlakuan yang diberikan oleh guru sehingga dapat mengkonstruksikan pengetahuan itu dalam kehidupan sehari-hari. Ilmu Pengetahuan Alam berkaitan dengan cara mencari tahu tentang alam secara sistematis, sehingga IPA bukan hanya penguasaan kumpulan pengetahuan yang berupa fakta-fakta, konsep-konsep, atau prinsip-prinsip saja tetapi juga merupakan suatu proses penemuan. IPA diperlukan dalam kehidupan sehari-hari untuk memenuhi kebutuhan manusia melalui pemecahan masalah yang dapat diidentifikasikan. Penerapan IPA perlu dilakukan secara bijaksana untuk menjaga dan memelihara kelestarian lingkungan.

IPA merupakan suatu rangkaian konsep yang saling berkaitan. Dengan baganbagan konsep yang telah berkembang sebagai suatu hasil eksperimen dan observasi, yang bermanfaat untuk eksperimentasi dan observasi lebih lanjut (Depdikbud,2006). Materi Persilangan pada Makhluk Hidup merupakan materi yang ada di kelas IX SMP Semester 2. Materi Persilangan Makhluk Hidup merupakan bagian dari kelangsungan hidup makhluk hidup. Pembelajaran pada materi ini mengenalkan tentang proses persilangan dan hasil persilangan serta penerapannya. Materi persilangan ini akan mudah di pahami siswa bila ada keterlibatan siswa secara langsung dan memahami terminologi persilangan dengan cara menggunakan skema proses persilangan.

Studi ilmiah pertama yang mempelajari tentang sifat yang diturunkan dari generasi ke generasi berikutnya dilakukan oleh John Gregor Mendel. Mendel dianggap sebagai peletak dasar prinsip-prinsip hereditas yang kemudian diberi nama Hukum Mendel. Oleh karena itu Mendel dikenal sebagai Bapak Genetika. Dalam percobaannya Mendel menggunakan tumbuhan ercis atau kapri. Setelah Mendel melakukan percobaan berulang-ulang dengan hasil yang sama, maka dibuatlah kesimpulan sebagai berikut: Hukum Mendel 1 (Hukum Pemisahan Gen yang 
Sealel/Segregasi) mengemukakan bahwa dua gen akan berpisah pada saat pembentukan gamet. Hukum Mendel 2 (Hukum Pengelompokan Gen secara Bebas/Asortasi) dijelaskan bahwa gen yang telah terpisah pada pembentukan gamet akan bergabung dengan gen-gen dari induk lainnya pada saat perkawinan, penggabungan gen tersebut terjadi secara acak dan bebas.

Pada materi persilangan tingkat SMP yang dibahas meliputi : (1) Persilangan Monohibrida dominan penuh dan Intermediet Persilangan monohibrida dominan penuh adalah persilangan dua individu sejenis yang mempunyai sifat dominan penuh dengan individu lain yang bersifat resesif. Persilangan monohibrida dominan penuh menghasilkan individu F1 yang memiliki fenotif yang sama dengan sifat induk yang dominan. (2) Persilangan Dihibrida pada kenyataannya, setiap individu mempunyai lebih dari satu sifat beda. Mendel juga melakukan percobaan dengan mengadakan persilangan antara dua tumbuhan kacang ercis yang memiliki dua sifat beda. (3) Menentukan gamet dari genotif tetua, dalam persilangan monohibrida diketahui bahwa gamet yang terbentuk pada P2 ada 2 macam, sementara itu pada persilangan dihibrida yang terbentuk pada $\mathrm{P} 2$ ada 4 macam, untuk persilangan trihibrida ada 8 macam, bila persilangan dengan $\mathrm{n}$ sifat beda akan diperoleh $2^{\mathrm{n}}$ macam gamet. Untuk menemukan macam gamet yang terbentuk dapat digunakan diagram garpu. (4) Menentukan rasio genotif dan fenotif.

Metode Pembelajaran Tutor Sebaya yaitu sekelompok siswa yang telah tuntas terhadap bahan pelajaran, dan memberikan bantuan kepada siswa yang mengalamai kesulitan dalam memahami bahan pelajaran yang dipelajarinya. Seorang atau beberapa orang siswa yang ditunjuk oleh guru, untuk membantu guru dalam melakukan bimbingan terhadap kawan sekelas. Dengan sistem pembelajaran menggunakan tutor sebaya, akan membantu siswa yang mencapai nilai Kriteria Ketuntasan Minimal (KKM) atau kurang cepat menerima pelajaran dari guru (Herianto dkk, 2010:2).

Tutor sebaya dikenal dengan pembelajaran teman sebaya atau pemberian pembelajaran antar siswa atau peserta didik. Hal ini merupakan strategi untuk mendukung pengajaran sesama peserta didik didalam kelas. Strategi ini menempatkan seluruh tanggung jawab pengajaran kepada seluruh anggota kelas (Setiawati, 2009:9). Pembelajaran tutor sebaya dapat meningkatkan hasil belajar siswa, sumber belajar tidak hanya dari guru melainkan dari teman sekelas yang nilai KKMnya lebih tinggi. Tutor berfungsi sebagai pelaksana mengajar yang cara mengajarkan telah disiapkan secara khusus dan terperinci. Peran tutor sangat besar pengaruhnya terhadap keberhasilan kelompok dalam mempelajari mata pelajaran yang disajikan melalui metode tutor sebaya (Herianto dkk 2010:2-3).

Karakteristik tutor sebaya menurut Surya (dalam Soeprodjo dkk, 2008:295) Metode tutor sebaya merupakan metode yang dilakukan dengan cara memperdayakan kemampuan siswa yang memiliki daya serap tinggi, siswa tersebut mengajarkan materi atau latihan kepada teman-temannya yang belum paham, Pemakaian tutor dari teman 
mereka memungkinkan siswa tidak merasa enggan untuk bertanya, dengan adanya tutor dapat memberikan keringanan pada guru dalam memberikan contoh soal atau latihan. Peran guru adalah mengawasi kelancaran pelaksanaan metode ini dengan memberi pengarahan dan lain-lain. Dalam memilih tutor sebaya hendaknya diperhatikan segi kemampuan dalam penguasaan materi dan kemampuan dalam membantu orang lain.

Ini berarti bahwa tutor adalah murid yang tergolong baik dalam prestasi. Ada beberapa keuntungan metode tutor sebaya antara lain, (1) adanya suasana hubungan lebih akrab antara murid dengan tutor, (2) bersifat efisien, (3) bagi tutor merupakan pengayaan, (4) dapat meningkatkan rasa tanggung jawab. Namun demikian ada kekurangan yaitu guru harus tahu siswa yang mempunyai pemahaman lebih, pengawasan tutor harus dilakukan dengan baik dan proses tutoring akan terhambat manakala siswa yang ditutori merasa rendah ini. Permasalahan dalam metode ini antara lain apabila di dalam kelas tidak ada yang mampu dan bersedia menjadi tutor sebaya. Tutor sebaya menurut Djamarah dan Zain ( dalam Azimatul dan Rosijono, 2010:30) adalah pembelajaran yang terpusat pada siswa, dalam hal ini siswa belajar dari siswa lain yang memiliki status umur, kematangan/harga diri yang tidak jauh berbeda dari dirinya sendiri.

Dari pengertian di atas dapat diambil kesimpulan bahwa pembelajaran tutor sebaya merupakan pembelajaran yang melibatkan siswa sekelas yang memiliki kemampuan dan kreteria sebagai tutor untuk membimbing teman lainnya yang mengalami kesulitan dalam memahami penjelasan dari gurunya. Tutor sebaya adalah seseorang atau beberapa orang siswa yang ditunjuk stau ditugaskan untuk membantu siswa dalam mengalami kesulitan belajar. Menurut Gintings (dalam Azimatul dan Rusijono, 2010:30) penjelasan mengenai tahapan-tahapan kegiatan pembelajaran dengan menggunakan pembelajarantutor sebaya. Tahapan-tahapan tersebut adalah sebagai berikut: a) Langkah perencanaan, b) Langkah persiapan, c) Langkah pelaksanaan, d) Langkah evaluasi.

Kriteria dari Tutor Sebaya antara lain Seorang tutor hendaknya memiliki kriteria yaitu, memiliki kemampuan akademik di atas Kriteria Ketuntasan Minimal (KKM) siswa satu kelas, mampu menjalin kerja sama dengan sesama siswa, memiliki motivasi tinggi untuk meraih prestasi akademik yang baik, memiliki sifat tolenransi dan tenggang rasa dengan sesama, memiliki motivasi tinggi untuk menjadikan kelompok diskusinya sebagai yang terbaik, bersikap rendah hati, pemberani, dan bertanggung jawab, suka membantu sesamanya yang mengalami kesulitan.

Selain kriteria diatas sebagai tutor memiliki tugas dan tanggung jawab untuk (1) memberikan tutorial kepada anggota terhadap materi ajar yang sedang dipelajari, (2) mengkoordinir proses diskusi agar berlangsung kreatif dan dinamis, (3) menyampaikan permasalahan kepada guru pembimbing apabila ada materi ajar yang belum dikuasai, (4) menyusun jadwal diskusi bersama anggota kelompok, baik pada saat tatap muka di kelas maupun di luar kelas, secara rutin dalam memecahkan masalah yang dihadapi, (5) melaporkan perkembangan akademis kelompoknya kepada guru pembimbing pada setiap 
materi yang dipelajari, peran guru dalam metode dengan tutor sebaya hanyalah sebagai fasilitator dan pembimbing terbatas. Artinya guru hanya melakukan intervensi ketika betul-betul diperlukan oleh siswa (Setiawati, 2009:11).

Adapun beberapa Kelebihan Tutor Sebaya yaitu anak-anak diajarkan untuk mandiri, Siswa lebih mudah dan leluasa dalam menyampaikan masalah yang dihadapi, Membuat siswa yang kurang aktif menjadi aktif, Membantu siswa yang kurang mampu atau kurang cepat menerima pelajaran dari gurunya, Tutor maupun yang ditutori samasama diuntungkan, bagi tutor akan mendapat pengalaman, sedang yang ditutori akan lebih kreatif dalam menerima pelajaran. Adapun beberapa kekurangan dari tutor sebaya yaitu Tidak semua siswa dapat menjelaskan kepada temannya, Tidak semua siswa dapat menjawab pertanyaan temannya. Cara mengatasi kekurangan tutor sebaya, para tutor dilatih untuk mengajar berdasarkan silabus yang telah ditentukan. Muntansir(1985:58) menyatakan "dalam kegiatan ini tutor dan guru menjadi semacam staf ahli yang mampu mengatasi kesulitan yang dihadapi murid, baik dengan cara satu lawan satu maupun kelompok kecil". Pembelajaran model tutor sebaya merupakan implementasi dari Kurikulum Tingkat Satuan Pendidikan (KTSP). Dasar pertimbangan pelaksanaan pembelajaran ini adalah karena selama ini pembelajaran IPA di sekolah Menengah Pertama siswa terlihat jenuh karena kurang diberdayakan oleh guru, mereka diperlakukan hanya sebagai objek yang harus duduk manis mendengarkan dan memperhatikan guru menerangkan tanpa adanya umpan balik. Dengan diterapkannya Metode Belajar Tutor Sebaya dapat meningkatkan Hasil Belajar IPA materi proses persilangan pada siswa kelas IXD semester 2 tahun pelajaran 2017/2018 di SMP Negeri 3 Trenggalek.

\section{METODE PENELITIAN}

Penelitian ini merupakan Penelitian Tindakan Kelas (PTK) atau Classroom Action Research, yaitu suatu penelitian yang mengkaji proses pembelajaran dikaitkan dengan pengoptimalkan penggunaan metode pembelajaran. Penggunaan penelitian jenis tindakan ini sesuai dengan pernyataan Creswell (2012:589) bahwa penelitian tindakan dapat digunakan untuk menyelesaikan suatu masalah khususnya yang terkait dengan situasi atau komunitas kerja peneliti. Dengan penelitian ini diharapkan dapat meningkatkan proses dan hasil pembelajaran sesuai dengan tujuan yang ditetapkan sebelumnya.

Menurut Kurt Lewin (dalam Wahidmurni \& Ali, 2008: 41) penelitian tindakan meliputi 4 tahap yaitu: (1) perencanaan, (2) tindakan, (3) pengamatan (4) refleksi. Sedangkan menurut Kemmis \& Mc Taggart (dalam Wahdmurni \&Ali, 2008:41) disebutkan bahwa tahap tindakan dan pengamatan dijadikan satu kesatuan. Disatukannya kedua komponen tersebut disebabkan oleh adanya kenyataan bahwa tindakan dan pengamatan merupakan dua kegiatan yang tidak terpisahkan. Sedangkan dalam penelitian ini menggunakan 4 tahapan yaitu :(1) tahap perencanaan, yakni mengemukakan persiapan 
yang dilakukan sehubungan akan dilakukannya PTK, (2) pelaksanaan tindakan, yaitu jabaran tindakan yang dilakukan, skenario kerja tindakan perbaikan dan prosedur tindakan yang dilakukan, (3) observasi, merupakan kegiatan pengumpulan data. Ketika observasi berlangsung peneliti mengumpulkan data proses pembelajaran yang meliputi akstivitas guru, aktivitas siswa, interaksi siswa dengan guru, interaksi siswa dengan siswa yang lain, atau semua fakta yang dan selama proses pembelajar berlangsung, (4) refleksi, merupakan kegiatan untuk menganalisa, mensintesis, dan menyimpulkan. Keempat komponen penelitian tindakan ini masuk kedalam siklus PTK.

\section{HASIL DAN PEMBAHASAN}

Pada pembelajaran IPA materi proses pewarisan sifat pada awalnya/tahap pra siklus dilakukan dengan metode diskusi kelas dan kelompok yang mana anggota kelompoknya cukup banyak, ternyata kurang efisien dalam hal pemahaman materi dan juga waktu . Disebabkan jumlah anggota tiap kelompok terlalu banyak dan hanya siswasiswa yg aktif saja yang mau mengerjakannya, sehingga berakibat pada hasil ulangan. Dimana dari 32 siswa yang mencapai nilai KKM hanya 13 anak sehingga presentasinya hanya mencapai 40,62\%, sedangkan 19 anak tidak mencapai KKM dengan presentase sebesar $59,38 \%$.

Berdasarkan permasalahan yang dihadapi mendorong peneliti untuk mengadakan penelitian tindakan kelas dengan menggunakan metode tutor sebaya, tujuan peneliti dengan metode tutor sebaya ini bisa menolong siswa yang malu atau takut bila bertanya langsung ke guru.

Tabel 1. Rekapitulasi hasil test siklus I

\begin{tabular}{|l|l|l|l|l|l|}
\hline No & Nilai $(X)$ & Frekwensi & FX & Persentsi & Ketengan \\
\hline 1 & 100 & 1 & 100 & 3,13 & \\
\hline 2 & 92 & 1 & 92 & 3,13 & \\
\hline 3 & 88 & 3 & 264 & 9,38 & \\
\hline 4 & 84 & 1 & 84 & 3,13 & \\
\hline 5 & 80 & 6 & 480 & 18,75 & \\
\hline 6 & 76 & 8 & 608 & 25 & \\
\hline 7 & 68 & 2 & 136 & 6,25 & \\
\hline 8 & 64 & 1 & 64 & 3,13 & \\
\hline 9 & 60 & 1 & 60 & 3,13 & \\
\hline 10 & 52 & 2 & 104 & 6,25 & \\
\hline 11 & 48 & 2 & 96 & 6,25 & \\
\hline 12 & 40 & 1 & 40 & 3,13 & \\
\hline 13 & 32 & 2 & 64 & 6,25 & \\
\hline 14 & 28 & 1 & 28 & 3,13 & \\
\hline
\end{tabular}




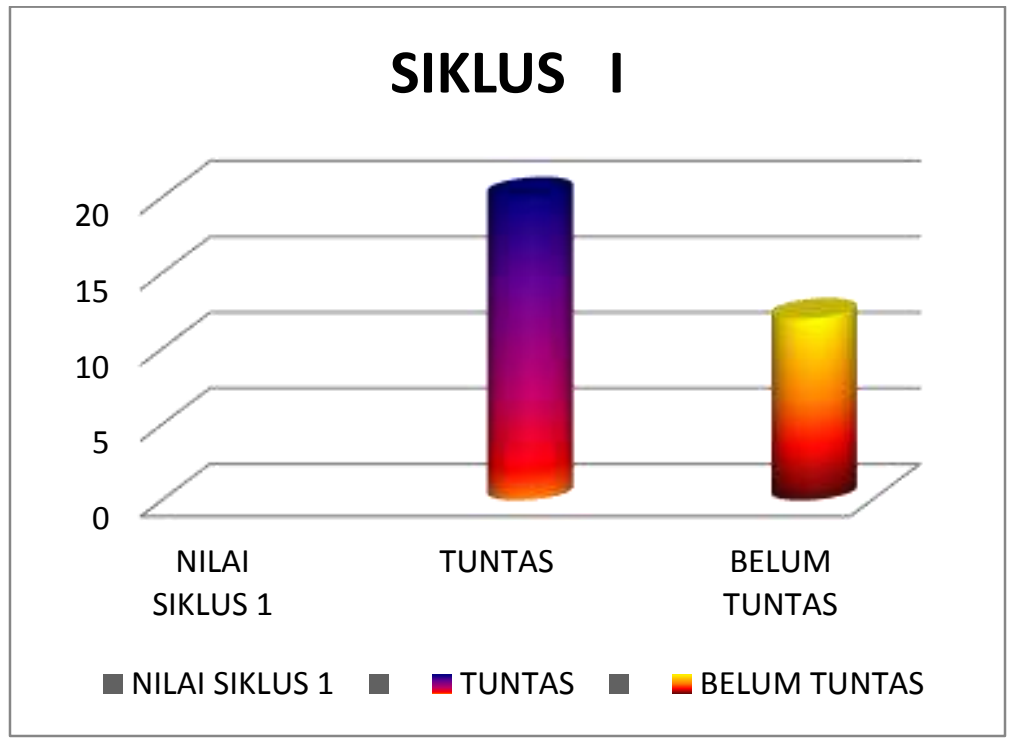

Gambar 1. Diagram Hasil Evaluasi Siklus I

Dari hasil observasi terhadap hasil belajar siswa dan tutor sebaya , maka peneliti memperoleh beberapa kelemahan yaitu :

a. Kurang mempersiapkan siswa yang berperan sebagai tutor dalam penguasaan materi dan kemampuan komunikasi dengan teman-teman, sehingga tutor sebaya belum optimal dalam menyampaikan materi.

b. Peneliti sebagai nara sumber dalam kegiatan pembelajaran belum optimal dalam membantu siswa yang masih belum menguasai materi

c. Kurang adanya motivasi dan antusias siswa dalam pembelajaran, kurang adanya kerjasama antar sesama anggota kelompok dan siswa yang ditutori masih memiliki rasa malu untuk bertanya kepada tutornya

Dengan adanya kelemahan-kelamahan tersebut maka perlu adanya perbaikan pada siklus 2, dengan langkah-langkah sebagai beriku:

1) Lebih mengoptimalkan penguasaan materi bagi tutor dengan cara ditingkatkan proses pembimbingan

2) Peneliti lebih optimal dalam membantu siswa yang belum menguasai materi 
Tabel 2 Rekapitulasi hasil test siklus II

\begin{tabular}{|c|c|c|c|c|c|}
\hline No & Nilai $(X)$ & Frekwensi & FX & Persentsi & Ketengan \\
\hline 1 & 92 & 4 & 368 & 12,5 & \\
\hline 2 & 88 & 1 & 88 & 3,13 & \\
\hline 3 & 84 & 7 & 588 & 21,87 & \\
\hline 4 & 80 & 6 & 480 & 18,75 & \\
\hline 5 & 76 & 8 & 608 & 25 & \\
\hline 6 & 68 & 2 & 136 & 6,25 & \\
\hline 7 & 60 & 2 & 120 & 6,25 & \\
\hline 8 & 56 & 1 & 56 & 3,13 & \\
\hline 9 & 40 & 1 & 40 & 3,13 & \\
\hline
\end{tabular}

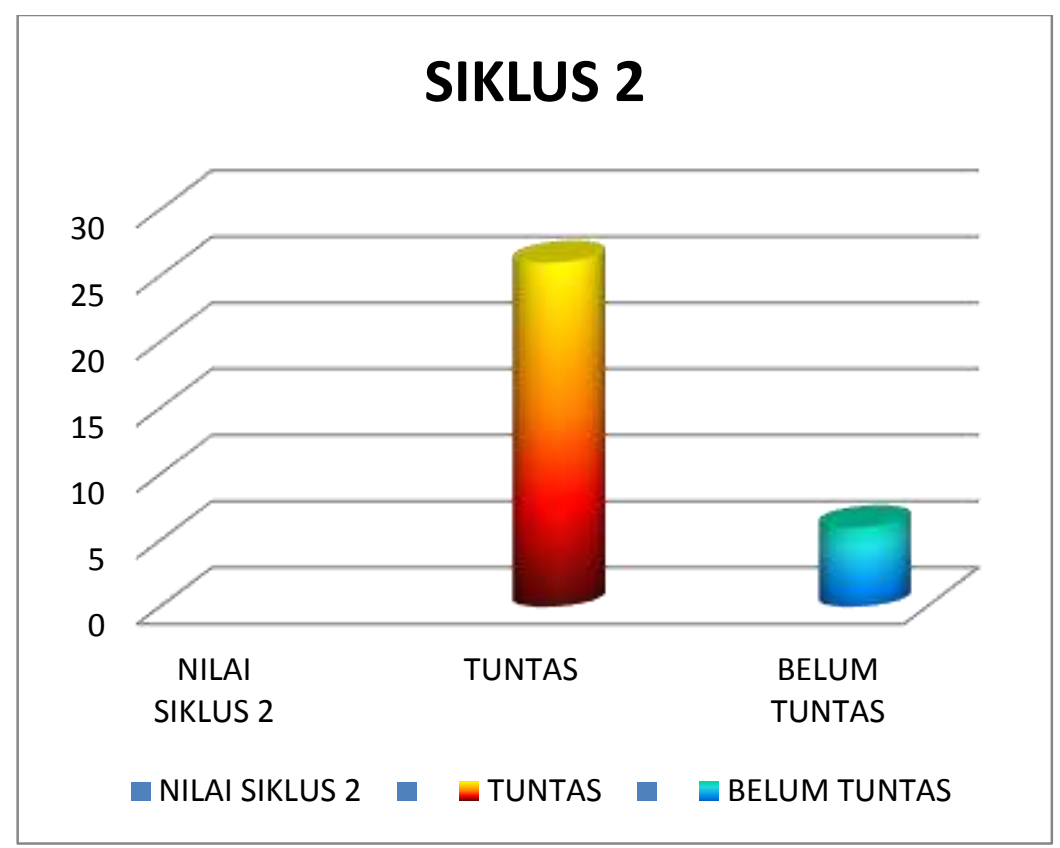

Gambar 2. Diagram Hasil Evaluasi Siklus II

Tahap ini sudah ada peningkatan dari peneliti dalam mengelola kelas dan mengalokasikan waktu sesuai dengan perencanaan, dan siswa lebih aktif dalam mengikuti proses pembelajaran. Dalam diskusi kelompok telah terjadi kerja sama antar siswa dan dengan tutor saling memotivasi sehingga proses pembelajaran berjalan lancar sesuai dengan waktu yang telah dialokasikan. Hal ini terlihat dari meningkatnya nilai tes pada siklus II. Perbandingan Peningkatan Prestasi Belajar dari Pra Siklus, Siklus 1dan Siklus 2 dapat kita lihat pada grafik berikut 


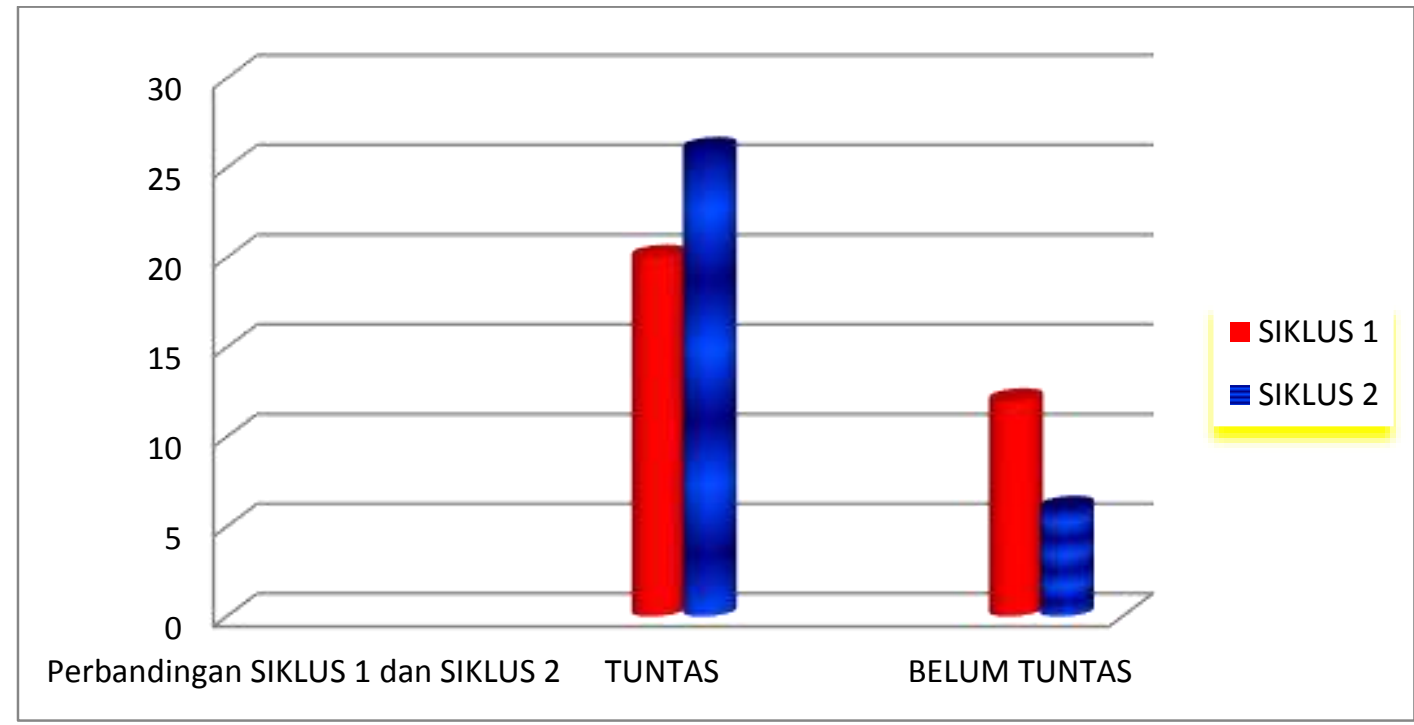

Gambar 3. Perbandingan siklus 1 dan siklus 2

Berdasarkan observasi hasil evaluasi siswa dari siklus I dan siklus II , diketahui bahwa ada peningkatan perolehan total skor dalam proses pembelajaran. Adapun perolehan hasil evaluasi siswa dapat dilihat pada diagram diatas . Dari diagram di atas dapat diketahui bahwa siswa yang tuntas pada siklus I sebanyak 20 siswa (62,5\%), dan mengalami peningkatan pada siklus II menjadi sebanyak 26 siswa $(81,25 \%)$ siswa yang tuntas. Sebaliknya siswa yang belum tuntas pada siklus I sebanyak 12 siswa (37,5\%) dan mengalami penurunan pada siklus II menjadi 6 siswa (18,75\%) yang belum tuntas.

Peningkatan jumlah siswa yang tuntas pada siklus II ini tidak lepas dari beberapa faktor penyebab antara lain 1) Tutor sebaya lebih memahami materi dan tugasnya karena sebelumnya sudah dimantapkan lagi pemahaman materinya. 2) Waktu pembelajaran lebih efektif karena siswa yang dibimbing oleh tutor sudah tidak malu bertanya dan sudah lebih percaya dengan kemampuan tutor sebayanya.

\section{KESIMPULAN DAN SARAN KESIMPULAN}

Berdasarkan hasil pengamatan penelitian dari siklus I dan siklus II dapat diambil kesimpulan bahwa penggunaan metode tutor sebaya dalam penelitian ini , menunjukkan adanya peningkatan kemampuan siswa dalam mempelajari materi proses persilangan. Hal ini dapat dilihat dari perbandingan antara nilai akhir siklus 1 sebesar $62,5 \%$ dengan nilai akhir siklus 2 sebesar $81,25 \%$. Jadi dalam penelitian ini terjadi kenaikan hasil belajar sebesar $18,75 \%$. 


\section{SARAN}

Setelah diketahui hasil akhir dari penelitian ini yang tertuang dalam kesimpulan, maka peneliti memberikan saran sebagai berikut :

1) Bagi peneliti atau guru pada umumnya, harus dapat memilih metode dan kreatif dalam mencoba ide-ide baru untuk peningkatan proses pembelajaran . Selain itu perlu mencoba metode tutor sebaya pada materi IPA yang lain.

2) Bagi siswa harus membiasakan atau sering menggunakan metode pembelajaran tutor sebaya , agar lebih terjalin keterikatan antara siswa yang satu dengan yang lainnya sehingga siswa merasa nyaman dalam proses pembelajaran.

3) Bagi lembaga atau sekolah sebagai bahan masukan yang positif dalam peningkatan profesi guru dengan mempertimbangkan tingkat kreatifitas guru dalam merancang sistem pembelajaran yang aktif, kreatif, dan menyenangkan.

\section{DAFTAR PUSTAKA}

Arikunto, Suharsimi. 1999. Prosedur Penelitian Suatu Pendekatan Praktis.Jakarta Rineka Cipta.

Azimatul, I. Dan Rusijono. 2010. Pengaru Penerapan Pembelajaran Tutor Sebaya Terhadap Hasil Belajar TIK. Journal Teknologi Pendidikan. Vol. 10.

No.2 2010, hlm 26-37.

Conny Semiawan. 1990. Pendekatan Ketrampilan Proses. Jakarta : PT. Gramedia.

Creswell, John W. 2012. Planning, Conducting, and Evaluating Quantitative andQualitative Research. Boston: Pearson.

Depdiknas, 2006. Kurikulum Tingkat Satuan Pendidikan. Jakarta. Depdiknas

Herianto, D. Persaoran. S. Jajang. K. 2010. Efektifitas Model Pembelajaran Tutor Sebaya terhadap Hasil Belajar Siswa. Bandung: Skripsi. Universitas Pendidikan Indonesia. Bandung.

Hamalik, Oemar. 2004. Proses Belajar Mengajar. Jakarta : Bumi Aksara

Leo Sutrisno. 2008. Pengertian Hasil Belajar . http://aadesenjaya.blogspot.com/2011/03/pengertian-devinisi-hasil belajar.html

Muntansir. 1985. Pengertian Tutor Sebaya. http://smkswadayatmg. Penerapan Metode Tutor Sebaya dalam upaya mengoptimalkan pembelajaran mata pelajaran matematika. Wordpress.com/xmlrpc.php.

Setiawati, D. 2009. Perbandingan Hasil Belajar Peserta Didik yang menggunakan Metode

Diskusi Kelompok Model Tutor Sebaya dengan yang menggunakan Metode

Diskusi Kelompok Biasa Untuk Mata Pelajaran Biologi di SMA Negeri 1 Indralaya. Skripsi. Indralaya: FKIP Universitas Sriwijaya.

Soeprodjo,Eko Budi, S. Sukron. 2008. Komparasi Hasil Belajar dengan Metode Tutor Sebaya dan Team Work Learning dalam pembelajaran kimia. Journal Inovasi Pendidikan Kimia, Vol2 No 2, 2008 hlm 294-298.

Usman, Uzer M. 2002. Menjadi Guru Profesional. Edisi Kedua. Cetakkan ke empat belas. Bandung : PT Remaja Rosdakarya.

Tim MGMP IPA Terpadu SMP. 2017. Lembar Kerja Siswa. Trenggalek: MGMP IPA SMP Kabupaten Trenggalek. 
Wahidmurni dan Ali, Nur 2008. Penelitian Tindakan Kelas Pendidikan Agama dan umum: Dari Teori Menuju Praktik Disertai ContohHasil Penelitian. Malang: UM Press. 